\title{
WAJIB PAJAK DAN KEPATUHAN DALAM PEMBAYARAN PBB P2
}

\section{TAXPAYERS AND PAYMENT COMPLIANCE OF PBB P2}

\author{
A. B. Setiawan, Y Rohmatiani \\ Jurusan Akuntansi Fakultas Ekonomi Universitas Djuanda Bogor \\ E-mail : ade.budi.setiawan@unida.ac.id \\ yevi.rohmatiani@unida.ac.id
}

\begin{abstract}
Tax compliance in paying taxes is a strategic position in terms of increased tax revenue, but for more than two years there are still taxpayers who are less adherent to the realization of tax payments so that the target is not reached. Factors influencing adherence among others are the level of income, taxes and control knowledge is the village clerk. Meode research is descriptive with a population of 250532 Taxpayer and samples taken as many as 400 taxpayers. The analysis technique used is regression bergandan with instrument data using classic assumption test. Research results Indicate that the level of income, tax knowledge and control of the village clerk and simultaneous partial effect of compliance with tax payment in Bogor. The contribution of income level, knowledge of tax and villages reviewing official control of compliance with tax payment in the amount of 54.2 percent
\end{abstract}

Keywords: Land and Building Tax, Compliance, income level, tax knowledge, control officers village

\begin{abstract}
ABSTRAK
Kepatuhan wajib pajak dalam membayar pajak merupakan posisi strategis dalam hal peningkatan penerimaan pajak, akan tetapi selam dua tahun ini masih terdapat wajib pajak yang kurang patuh terhadap pembayaran pajak sehingga target realisasi tidak tercapai. Faktor yang berpengaruh terhadap kepatuhan tersebut antara lain adalah tingkat pendapatan, pengetauan pajak dan kontrol petugas kelurahan. Penelitian yang digunakan adalah meode deskriptif dengan populasi sebanyak 250.532 Wajib Pajak dan sampel yang diambil sebanyak 400 Wajib Pajak. Teknik analisis yang digunakan adalah regresi bergandan dengan instrument data menggunakan uji asumsi klasik. Hasil penelitian menunjukkan bahwa tingkat pendapatan, pengetahuan pajak dan kontrol petugas kelurahan berpengaruh secara parsial dan simultan terhadap kepatuhan pembayaran PBB di Kota Bogor. Besarnya kontribusi tingkat pendapatan, pengetahuan pajak dan kontrol petuas kelurahan terhadap kepatuhan pembayaran PBB P2 yaitu sebesar 54,2 persen
\end{abstract}

Kata kunci: PBB, Kepatuhan,Tingkat pendapatan, pengetahuan pajak, kontrol petugas kelurahan 


\section{PENDAHULUAN}

Pemerintah dalam penyelenggaraan Negara mempunyai sumber penerimaan Negara untuk menjalankan pemerintahannya. Sumber penghasilan Negara menurut UU No 17 Th 2003 mengenai Keuangan Negara, pendapatan Negara dan hibah ialah seluruh pedapatan Negara yang berasal dari pendapatan pajak, penerimaan Negara non pajak, beserta penerimaan hibah dari dalam dan luar negeri. Penerimaan pajak selalu pengalami kenaikan dibanding dengan penerimaan non pajak. Hal ini diiringi dengan tingginya APBN setiap tahunnya sehingga membuat tugas DJP (Direktorat Jenderal Pajak) Harus dengan usaha menjalankan upaya agar meningkatnya jumlah penerimaan pajak. Penggunaan hasil dari pajak mencakup belanja pegawai serta untuk membiayai macam-macam objek pembangunan, contohnya jembatan, rumah sakit/puskesmas, sekolah, dst yang dibiayai menggunakan hasil dari pajak (pajak.go.id).

UU No. 28 TH 2007 pasal 1 mengenai ketentuan umum perpajakan, pajak merupakan suatu kontribusi yang wajib untuk Negara yang terhutang ole orang pribadi maupun badaan yang sifatnya memaksa, dengan demikian tetap berlandaskan kepada Undang undang, dan tidak dapat balasan secara langsung dan dipakai untuk kepentingan Negara serta kemakmuran rakyatnya. Menurut Soemitro pajak ialah bayaran atau pungutan masyarakat untuk kas Negara berlandaskan undang-undang dan tidak memperoleh jasa imbang secara langsung yang bisa diperuntukan dan dipakai guna membayar pengeluaran umum Negara. PBB mempunyai nilai uang lebih sedikit jika kita bandingkan dengan jenis pajak lainnya, akan tetapi PBB memiliki dampak yang luas. Hal ini diakibatkan hasil pendapatan pemerintah yang beasal dai PBB selanjutnya dikembalikan untuk pengembangan wilayah yang bersangkutan. Dengan demikian, diharapkan pemerintah sekitar juga dapat mengelola pendapatan tersebut untuk kemudian dapat menjadikan daerahnya mencapai kesejahteraan. Penjelasan lainnya, PBB juga memiliki wajib pajak terbesar dibandingkan pajak-pajak sejenisnya, pendapatan PBB tiap periode selalu bertambah serta mempunyai persentase lebih banyak dari pada persentse peningkatan pajak lain dan APBN (Suhardito dan Sudibyi,1999). Kenaikan penerimaan PBB juga karena ada kesadaran untuk menyetor pajak.

Kepatuhan dari orang yang membayar pajak dibutuhkan demi kelancaran penarikan pajak. Begitu pun untuk penarikan PBB diharapkan kepatuhan yang tinggi dari Wajib Pajakk PBB. Kepauhan wajib pajak ialah suatu kondisi agar wajib pajak melaksanakan seluruh tanggungan perpajakan dan menjalankan hak perpajakan. Namun pada kebenarannya yang berlangsung pemerintah mengalami kendala dalam pembayaran pajak diantaranya ialah PBB. Dalam self assessment system, kepatuhan wajib pajak menjadikan salah satu kunci utama dalam mendukung keberhasilan pemungutan pajak.

Pajak perlu memperhatikan kapasitas orang dalam membayar, kemampuan membayar itu sendiri dipengaruhi dengan tingkat pendapatan, dan untuk itu pajak harus dibayar waktu yang tepat, yaitu pada saat wajib pajak mempunyai uang (Soemitro,1987) dan juga Ancok dalam Siamanjuntak (2008), tanpa adanya pengetahuan tentang pajak dan manfaatnya tidaklah mungkin orang akan tulus ikhlas membayar pajak. Upaya dalam memberikan penerangan akan dirasa kurang juka hanya ceramah dan pidato tatapi harus dicari cara yang dapat membuat orang ingat dan bangga akan tugas membayar pajak. Ridwan (2005) menjelaskan bahwa pada institusi pemerintah sumber daaya manusia disebut juga aparat, yaitu pegawai yang menjalankan tanggungg jaawab mengenai kelembagaan bagi seorang aparat pagawai yang telah diatur dalam tugas dan tanggung jawab terhadap pekerjaannya. Selanjutnya selain faktor-faktor tersebut mmpengaruhi kesadaran pembayaran PBB, sikap wajib pajak agar berperilaku benar atau tidak pun dilatarbelakangi oleh kontrol dari petugas kelurahan. Kontrol penagihan pajak yang dilaksanakan perangkat kelurahan bisa menjadikan tujuan yang melatarbelakangi sikap wajib pajak untuk bertindak patuh (Kartika, et al: 2016). 
Pada Tahun 2013 PBB P2 mulai ditangani oleh pemkot Bogor. semenjak perpindahan PBB P2 menjadi Pajak Daerah, Pemerintah Kota Bogor mampu melaksanakan tujuan dari UU PRDB tersebut. Berdasarkan laporan target dan realisasi penerimaan $\mathrm{PBB}$ P2 kota Bogor diketahui bahwa untuk Th 2015 telah ditetapkan target penerimaan PBB P2 sebesar 81 Milyar rupiah, naik dari 69.5 Milyar pada tahun 2014 namun itu sudah termasuk denda dan tunggakan (Dispenda Kota Bogor). Proses implementasi pengalihan PBB P2 ternyata masih menghadapi berbagai permasalahan diantaranya penerimaaan PBB perkecamatan di Kota Bogor tahun 2015 2016 dilihat pada tabel 1 berikut :

\begin{tabular}{|c|c|c|c|c|}
\hline $\begin{array}{l}\text { Kota } \\
\text { Bogor }\end{array}$ & $\begin{array}{c}\text { Tkt } \\
\text { Pencapaian } \\
(2015) \\
\end{array}$ & $\begin{array}{c}\text { Sisa } \\
\text { pokok } \\
\text { ketetapan }\end{array}$ & $\begin{array}{c}\text { Tkt } \\
\text { Pencapaian } \\
(2016) \\
\end{array}$ & $\begin{array}{c}\text { Sisa } \\
\text { pokok } \\
\text { ketetapan }\end{array}$ \\
\hline & $71,7 \%$ & $28,3 \%$ & $70,4 \%$ & $29,6 \%$ \\
\hline
\end{tabular}

Sumber : Bapenda 2017

Berdasarkan data bahwa penerimaan PBB Kota Bogor per kecamatan dari tahun 2015-2016 belum tercapai target dan tingkat pencapaian, secara persentase terjadi penurunan meskipun secara jumlah terdapat kenaikan nilai. Tidak tercapainya target mengidentifikasi masih terdapat permasalahan untuk usaha tercapainya target tersebut. Mengingat PBB P2 sebagai pajak baru untuk daerah maka dalam pengelolaannya tentunya ada kendala yang harus ditangani oleh pemerintah khusunya Kota Bogor, dan terbukti masih banyaknya WP yang kurang patuh dalam pembayar pajak

\section{Tinjauan Pustaka Tingkat Pendapatan}

\section{Pemungutan}

$$
\text { pajak perlu }
$$

memperhatikan kemampuan orang dalam membayar pajak, kemampuan membayar itu sendiri dipengaruh oleh tingkat pendapatan. Oleh karen itu pajak dipungut pada waktu yang tepat, yaitu saat wajib pajak mempunyai uang (Soemitro, 1987:26)

Adapun pendapatan keluarga menurut Aisyen (2010) ialah sebagai bagian hal yang dipentingkan untuk menjalankan keuangan keluarga, karena besarnya pendapatan yang dimiliki akan mempengaruhi berapa besar uang yang akan dikeluarkan. Penghasilan ialah gaji tetap yang didapatkan setiap bulan. Penghasilan mempunyai kaitan yang erat dengan kemampuan orang yang memenuhi kebutuhan gizi, perumahan yang sehat, pakaian dan kebutuhan lain yag berhubunga dengan pemeliharaan kesehatan.

\section{Pengetahuan Pajak}

Pengetahuan pajak yang juga pengertian dari aturan serta ketetapan perpajakan yang berlaku umum di Indonesia disarankan untuk dimiliki oleh semua wajib pajak. Dari adanya penjelasan yang benar mengenai pajak, diupayakan masyarakat agar meningkatkan kepatuhannya dalam menjalankan kewajibannya selaku warga Negra dengan membayar tepat waktu dan sesuai jumlah nominal yng seharusnya dibayarkan. Sebab itu, adanya fasilitas yang cukup untuk menunjang pengetahuan pajak dari wajib pajak menjadikan sesuatu hal yang diutamakan untuk catatan dalam pemahaman pajak. Tax knowledge is an essential element in a voluntary compliance tax system (Kasippilai, 2000 dalam Saad 2013), particulary in determining an accurate tax liability (Palil,2005 dalam Saad 2013) dengan demikian, penting untuk memiliki pengetahuan dan kompetensi pembayaran pajak.

\section{Kontrol Petugas}

\section{Definisi Kontrol Sosial}

Kontrol pendapat para ahli :

a. Peter I. Berger ialah bermacam starategi yang dipakai untuk mengatur orang yang menyalahi aturan.

b. Roucek \& Warren ialah proses yang tidak terencana untuk mengejar individu supaya dapat beradaptasi dengan kebiasaan dan nilai-nilai kelompok mereka mereka berada.

c. Soejono Soekarno ialah suatu jalan baik yang sudah direncanaka atau tidak, yang memiliki maksud mengajak, membimbing bahkan memaksa sekelompok orang untuk 
patuh terhadap nilai-nila dan kaidah yang berlaku

\section{Kepatuhan Membayar Pajak}

Putri (2014) Kepatuhan wajib pajak akan perpajakan yakni perasaan yang muncul dari diri sendiri atas kewajibannya mematuhi pajak dengan ikhlas tanpa adanya unsur dorongan dari orang lain. kepatuhan wajib pajak berkonsekuensi logis untuk par wajib pjak agar mereka dengan senang hati membayar kewajibannya untuk digunakan sebagai manfaat dari perpajakan.

Kondisi negara ini tidak terlepas dari kepatuhan masyarakatnya dalam membayar pajak. Kepatuhan masyarakat dalam membayar pajak sangat erat hubungnnya dengan kesadaran bernegara. Apabila kesadaran akan bernegara dirasa kurang maka masyarakat akan kurang mengenal dan mengetahui pentingnya berbangsa dan bertanah air, berbahasa nasional, merasakan keamanan dan ketertiban, merasa mempunyai serta menjiwai berbagai kebudayaan lokal dan pada akhirnya apabila kesadaran akan mencintai negara kurang maka rasa memiliki dan menikmati manfaat dari pengeluaran pemerintah pun akan berkurang sehingga kepatuhan membyar pajak juga berkurang.

\section{Pengembangan Hipotesis}

$H_{0}: \quad \beta 1, \quad \beta 2=0$; Tingkat pendapatan, pengetahuaan pajak dan kontrol petugas kelurahan tidak berpengaruh secara simultan terhadap kepatuhan PBB.

$H_{a}: \beta 1, \beta 2 \neq 0$; Tingkat pendapatan, pengetahuan pajak dan kontrol petugas kelurahan berpengaruh secara simultan terhadap kepatuhan PBB

Pentingnya pengetahuan pajak yang dimilki oleh wajib pajak mempengaruhi dalam kepatuhan membayar pajak, begitu pula tingkat pendapatan, menurut Aisyen (2010) besarnya uang yang masuk dapat mempengaruhi banyaknya uang yang dikeluarkan seseorang jadi, jika seseorang mempunyai pendapatan yang besar maka seharusnya wajib pajak patuh terhadap pembayaran $\mathrm{PBB}$ dan kontrol petugas kelurahan berperan penting dalam patuhnya wajib pajak dalam membaya $\mathrm{PBB}$, karena salah satu tujuan dari PBB yaitu untuk meningkatkan PAD dan memperbaiki strktur APBN.

$H_{0}: \beta_{1}=0$ Tingkat pendapatan, secara parsial tidak berpengaruh signifikan dan positif terhadap Kepatuhan pembayaran PBB.

$H_{a}: \beta_{1} \neq 0$ Tingkat pendapatan, secara parsial berpengaruh signifikan dan positif terhadap kepatuhan pembayaran PBB.

Pendapat Soemitro kemampuan membayar pajak dipengaruhi oleh tingkat pendapatan, oleh karena itu pajak harus dipungut pada saat yang tepat yaitu pada saat wajib pajak mempunyai uang.

$H_{o}: \beta_{3}=0$ Pengetahuan Pajak, secara parsial tidak berpengaruh signifikan dan positif terhadap Kepatuhan pembayaran PBB.

$H_{a}: \beta_{3} \neq 0$ Pengetahuan Pajak, secara parsial berpengaruh signifikan dan positif terhadap kepatuhan pembayaran PBB.

Variabel pengetahuan pajak memberikan pengaruh yang sangat besar terhadap kepatuhan wajib pajak, hal tersebut senada dengan yang diungkapkan oleh Ancok bahwa secara teoritik untuk menumbuhkan sikap positif terhadap suatu hal harus bermula dari adanya pengetahuan, tanpa adanya pengetahuan tentang pajak dan manfaatnya tidaklah mungkin orang akan tulus dan ikhlas dalam membayar pajak.

$H_{0}: \beta_{4}=0$ Kontrol Petugas Kelurahan secara parsial tidak berpengaruh signifikan dan positif terhadap kepatuhan pembayaran PBB

$H_{a}: \beta_{4} \neq 0 \quad$ Kontrol Petugas Kelurahan secara parsial berpengaruh signifikan dan positif terhadap kepatuhan pembayaran PBB

Sesuai dengan keputusan Menteri Keuangan RI No 1007/KMK.0411985 tentang pelimpahan wewenangan pungutan pajak kepada Gubernur kepala pemerintahan propinsi dan Walikota kepala pemerintahan kota dan Bupati kepala pemerintahan kabupaten untuk seterusnya diserahkan 
kepada organisasi dibawahnya untuk jalan mengoptimalkan penerimaan Negara yang berasal dari Pajak Bumi dan Bangunan, oleh karena itu, peran kepala daerah sangat dibutuhkan keaktifannya dalam hal pemungutan pajak ini. Oleh karena itu, peran kelurahan berperan penting dalam hal pemungutan pajak bumi dan bangunan pasca peralihan PBB dari pajak pusat menjadi pajak daerah. 


\section{Variabel Penelitian dan Operasional Variabel}

\section{Tabel 2 Operasional Variabel}

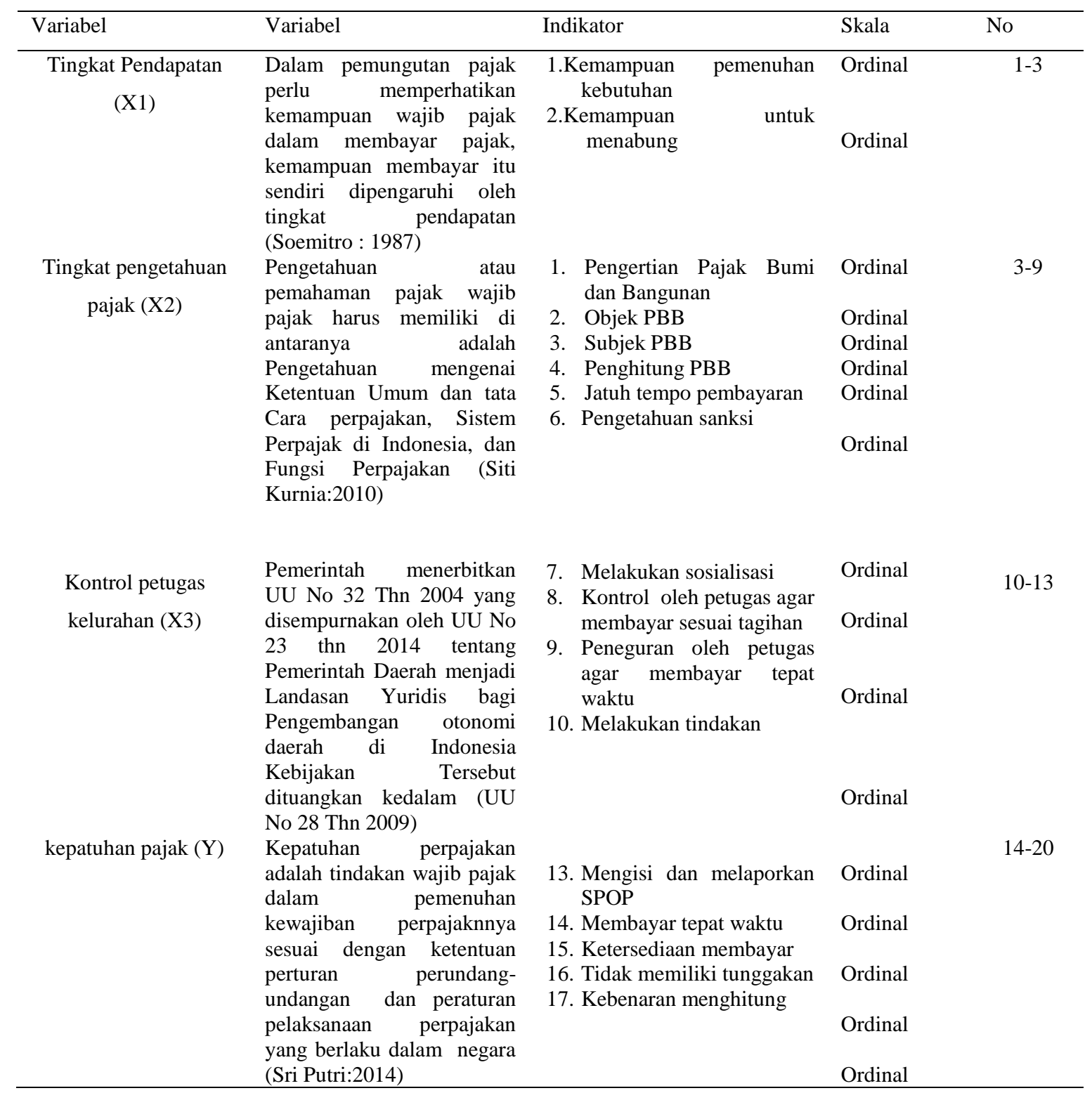


penelitian ini memiliki dua variabel, yaitu variabel bebas terdiri dari tingkat pendapatan $\left(X_{1}\right)$, pengetahuan pajak $\left(X_{2}\right)$ dan

\section{Populasi, Sampel dan Teknik Pengambilan Sampel}

Populasi untuk penelitian ini ialah Wajib Pajak orang pribadi atau badan PBB P2 di Kota Bogor. Rumus yang dipakai dalam mendapatkan sampel yaitu menggunakan rumus slovin :

$$
n=\frac{N}{N e^{2}}
$$

Keterangan :

$\mathrm{n}=$ Ukuran sampel

$\mathrm{N}=$ Ukuran Populasi

$\mathrm{e}=$ pesentase kelonggaran ketidakpastian dengan tingkat kesalahan 5\%

Berdasarkan rumus tersebut dapa ditentukan bahwa jumlah sampel pada penelitian ini sebanyak 400, dan untuk populasi berjumlah 250.532 jiwa yang terdaftar di Badan Pendapatan Daerah (BAPENDA) Kota Bogor.

\section{Pengujian Instrumen}

skala likert merupkan skala yang bisa dipakai dalam mengukur sikap, pendapat, dan pandangan seseorang tentang suatu objek atau fenomena tertentu, yang didata dari skala ordinal Untuk keperluan analisis kuantitatif, maka jawaban itu dapat diberi skor.

\section{Tabel 3 penilaian Kuesioner}

\begin{tabular}{lc}
\hline Jawaban Responden & Bobot Nilai \\
\hline Sangat Setuju & 5 \\
Setuju & 4 \\
Ragu-ragu & 3 \\
Tidak Setuju & 2 \\
Sangat tidak setuju & 1 \\
\hline \multicolumn{2}{c}{ Pengelolaan data ordinal menjadi } \\
analisis regresi terlebih dahulu harus \\
ditranformasikan ke bentuk data interval \\
dengan menggunakan rumus :
\end{tabular}

kontrol petugas kelurahan $\left(X_{3}\right)$. Sedangkan variabel terikat yaitu kepatuhan pembayaran PBB P2 $(Y)$ di Kota Bogor

$$
\begin{gathered}
\frac{\text { Nilai tertinggi }- \text { Nilai Terendah }}{\text { banyaknya Kelas }} \\
=0,8
\end{gathered}
$$

Setelah besarnya ditemukan, selanjutnya dibuat rentang skala agar dapat diketahui dimana rata-rata penilaian responden untuk setiap unsur diferensiasi dan seberapa jauh variasinya. Berdasarkan hasil perhitungan panjang kelas interval tersebut diperoleh kriteria penelitian pada tabel 3 berikut ini :

Tabel 4 Skala Penilaian

\begin{tabular}{cc}
\hline Skala & Interpresentasi \\
\hline $1,00-1,80$ & Sangat tidak setuju \\
$1,81-2,60$ & Tidak setuju \\
$2,61-3,40$ & Ragu-ragu \\
$3,41-4,20$ & Setuju \\
$4,21-5,00$ & Sangat setuju \\
\hline Sumber : Sugiyono, 2013 &
\end{tabular}

\section{Pengujian Validitas}

kuisioner dinyatakan valid jika pertanyaan pada kuisioner mampu untuk mengungkapkan sesuatu yang akan diukur oleh kuisioner tersebut (Ghozali,2006). Rumus yang digunakan adalah :

$$
r_{\text {hitung }}=\frac{n(\Sigma X Y)-(\Sigma X \Sigma Y)}{\sqrt{\left\{n \Sigma X^{2}-(\Sigma x)^{2}\right\}\left\{n \Sigma Y^{2}-(Y)^{2}\right\}}}
$$

Keterangan :

$\mathrm{r}_{\text {hitung }}=$ koefisien validitas item yang dicari

$\mathrm{n} \quad=$ Jumlah sampel

$\mathrm{x} \quad=$ Skor pernyataan

$\mathrm{Y}=$ Skor total pernyataan

$\Sigma \mathrm{x}=$ Jumlah skor dalam distribusi $\mathrm{x}$

$\Sigma \mathrm{x}^{2} \quad=$ Jumlah kuadrat pada masing-masing $\mathrm{x}$

$\Sigma \mathrm{y}^{2} \quad=$ Jumlah kuadrat pada masing-masing $\mathrm{y}$

Tabel 5 Kriteria Uji Validitas

\begin{tabular}{cc}
\hline $\begin{array}{c}\text { Corrected Item Total } \\
\text { Corelation }\end{array}$ & Keterangan \\
$\geq 0,3$ & Valid \\
$<0,3$ & Tidak Valid \\
\hline
\end{tabular}

Sumber : Sugiyono, 2013 


\section{Pengujian Reliabilitas}

Azwar (1997) reliabilitas adalah sejumlah hasil suatu pengukuran dapat dipercaya dan dapat memberikan hasil yang relatif tidak berbeda apabila dilakukan kembali kepada subjek yang sama.

$$
r_{\text {hitung }}=\frac{k}{(k-1)}\left(1-\frac{\Sigma S^{2}}{S^{2}}\right)
$$

$r_{\text {hitung }}=$ Reliabilitas instrumen

$\mathrm{k}$ = banyaknya pertanyaan

$\Sigma \mathrm{S}_{\mathrm{i}}{ }_{\mathrm{i}}=$ Jumlah varian butir

$\mathrm{S}_{\mathrm{i}}{ }^{2}=$ varian total

\section{tabel 6 Kriteria Uji Reliabilitas}

\begin{tabular}{cc}
\hline Alpha Cronbach & Keterangan \\
\hline$>0,6$ & Reliabel \\
$<0,6$ & Tidak Reliabel \\
\hline
\end{tabular}

Sumber : Sugiyono, 2013

\section{Uji Asumsi Klasik}

Merupakan persyaratan statistik yang harus dipenuhi dalam penggunaan analisis regresi berganda dan untuk memenuhi karakter koefisien regresi yang linier, tidak bias, konsisten, serta efisien (memiliki varians yang minimum). Uji asumsi klasik terdiri dari uji normalitas, uji multikolonieritas dan uji heterokedastisitas.

\section{Metode Analisis Data}

Sugiyono (2013) menyatakan bahwa teknik regresi linier berganda dipergunakan untuk mengetahui hubungan fungsional antara beberapa variable bebas terhadap variable terikat, dan untuk memperkirakan arah meramalkan bagaimana perunahan nilai variable dependen, bila nilai variable independen dinaikan atau diturunkan nilainya.

Bentuk persamaan regresi yang dirumuskan berdasarkan hipotesis yang dikembangkan dengan rumus berikut ini :

$$
\mathrm{Y}=\alpha+\beta_{1} X_{1}+\beta_{2} X_{2}+\beta_{3} X_{3}+\varepsilon
$$

Keterangan :

$Y \quad=$ Kepatuhan Pembayaran PBB

$\alpha \quad=$ Konstanta

$\beta \quad=$ Koefisien regresi

$X_{1}=$ Koefesien regresi tingkat pendapatan

$X_{2} \quad=$ Koefesien regresi pengetahuan pajak

$X_{3} \quad=$ Koefisien regresi kontrol petugas kelurahan

$\varepsilon \quad=$ Eror

\section{Koefisien Determinasi}

Koefisien determinasi (R2) bertujuan untuk mengukur sejauh mana kemampuan model dalam menerangkan variasi variabel dependen. Nilai koefisien determinasi antara nol dan satu. Nilai R2 yang dihasilkan kecil artinya kemampuan variabel-variabel independen amat terbatas. Nali yang mendekati satu berarti variabel-variabel independen memberikan hampir semua informasi yang dibutuhkan untuk memprediksi variabel yang dibutuhkan.

\section{Uji Hipotesis}

1. Uji Statistik F

Uji Statistik F pada umumnya memperlihatkan apakah seluruh variabel bebas yang dimasukkan dalam model mempunyai pengaruh secara bersam-sama terhadap variabel terikat

a. Kriteria Keputusan Uji F

1) Jika $F_{\text {hitung }}$ lebih besar dari $F_{\text {tabel }}$ ( $F_{\text {hitung }}>F_{\text {tabel }}$ ) dengan $\alpha=0,05$ maka Ho ditolak dan Ha diterima. Artinya Tingkat Pendapatan, Pengetahuan Pajak dan kontrol petugas kelurahan mempunyai pengaruh secara simultan terhadap Kepatuhan Pembayaran PBB.

2) Jika $F_{\text {hitung lebih kecil atau sama }}$ dengan dari $F_{\text {tabel }}\left(F_{\text {hitung }} \leq \mathrm{F}_{\text {tabel }}\right)$ ajakan, tingkat pendapatan dan pengetahuan Pdengan $\alpha=0,05$ maka Ho diterima dan Ha ditolak. Artinya tingkat pendapatan dan Pengetahuan Pajak dan kontrol petugas kelurahan tidak mempunyai pengaruh secara simultan terhadap Kepatuhan Pembayaran PBB.

\section{Uji Statistik t}

Uji statistik t pada dasarnya melihat sejauh mana pengaruh satu variabel penjelas/independen secara terpisah untuk menjelaskan variasi variabel dependen.

\section{Hasil dan Pembahasan}

Kota Bogor ialah sebuah daerah di Provinsi Jawa Barat, Indonesia. Kota ini berada $59 \mathrm{~km}$ disamping selatan Jakarta, dan daerahnya terletak di tengah-tengah daerah Kabupaten Bogor. sebelumnya luas Kota Bogor 21,56 $\mathrm{km}^{2}$, namun sekarang sudah 
bertambah menjadi $118,50 \mathrm{~km}^{2}$ dan total populasi 1.030.720 jiwa (2014). Bogor disebut atas predikat kota hujan, karena mempunyai curah hujan yang sangat besar. Kota bogor terdiri dari 6 Kecamatan dan dibagi lagi menjadi 68 Kelurahan. saat zaman Kolonial Belanda, Bogor disebut dengan sebutan Buitenzorg yang artinya "tanpa kecemasan" atau "aman tentram". Hari peringatan untuk Kabupaten Bogor dan Kota Bogor dirayakan setiap tanggal 3 Juni, karena tanggal 3 Juni 1482 menjadi peristiwa penobatan Prabu Siliwangi selaku raja dari Kerajaan Pajajaran. Bogor sudah lama dikenal dengan pusat pendidikan dan penelitian pertanian nasional. Disinilah beragam institusi dan balai pengkajian pertanian dan biologi berada mulai dari abad ke-19.

Berdasarkan jenis kelamin karakteristik wajib pajak menunjukan bahwa tingkat proporsi responden terbesar ialah yang berjenis kelamin laki-laki dengan jumlah responden sebanyak 237 orang $(59.25 \%)$, dan responden perempuan berjumlah 165 orang (41.25\%), dengan demikian dapat dikatakan bahwa sebagian dari wajib pajak yang membayar PBB adalah laki-laki, karena pada umumnya kepemilikan bumi dan atau bangunan jika mereka suami istri maka atas nama suami.

Berdasarkan pendidikan terakhir, karakteristik wajib pajak menunjukkan responden yang terbesar adalah SMU, yakni sebanyak 197 orang (49.25\%), posisi kedua yaitu tingkat pendidikan sarjana (S1) sebanyak 83 orang $(20.75 \%)$, posisi ketiga yaitu jenjang pendidikan SD sebanyak 52 orang (13\%), posisi keempat yaitu jenjang pendidikan DIII sebanyak 36 orang (9\%), untuk posisi kelima yaitu jenjang pendidikan SMP sebanyak 17 orang $(4.25 \%)$, kemudian posisi keenam yaitu jenjang pendidikan pascasarjana (S2) sebanyak 9 orang (2.25\%), dan yang terkecil yakni responden yang tidak sekolah sebanyak 6 orang $(1.5 \%)$.

berdasarkan pekerjaan, karakteristik wajib pajak bahwa mayoritas responden berprofesi sebagai karyawan swasta, yakni sebanyak 180 orang (45\%), dan selebihnya diikuti oleh Ibu Rumah Tangga, yakni sebanyak 119 orang (29.75\%), Pegawai Negeri Sipil berjumlah 52 orang (13\%), pengusaha sebanyak 35 orang $(8.75 \%)$, dan jenis pekerjaan lain berjumlah 14 orang (3.5\%). Adapun jenis pekerjaan lain-lain tersebut adalah buruh, supir dan serabutan.

Berdasarkan

penghasilan, karakteristik wajib pajak diketahui bahwa mayoritas responden mempunyai penghasilan sebesar 2.000.000 - 2.999.900 berjumlah102 orang $(25.5 \%)$, kemudian diikuti dengan penghasilan sebesar $1.000 .000-1.999 .900$ sebanyak 101 orang $(25.25 \%)$, responden yang mempunyai penghasilan $>4.000 .000$ sebesar 79 orang $(19.75 \%)$, responden yang mempunyai penghasilan 3.000 .000 3.999 .900 sebanyak 64 orang (16\%), dan yang terakhir sedikit responden yang memiliki penghasilan $>1.000 .000$ berjumlah 54 orang $(13.5 \%)$.

Berdasarkan rekapitulasi dari masingmasing responden , berikutnya akan dijelaskan rekapitulasi dari keseluruhan kriteria responden, ialah berikut : 
Tabel 7 Rekapitulasi Karakteristik Responden

\begin{tabular}{cccc}
\hline No & Kriteria Responden & Karakteristik & Jumlah/Orang \\
\hline 1 & Jenis Kelamin & Laka-laki & $237(59,25 \%)$ \\
2 & Pendidiakan & SMA & $197(49,25 \%)$ \\
3 & Pekerjaan & Karyawan Swasta & $180(45 \%)$ \\
4 & Penghasilan & $2.000 .000-2.999 .900$ & $102(25,5 \%)$ \\
Sumber : Data diolah 2017 & &
\end{tabular}

\section{Tingkat Pendapatan}

Rekapitulasi skor tanggapan wajib pajak PBB P2 terhadap Tingkat Pendapatan adalah :

Tabel 8 Rekapitulasi Skor Tanggapan Variabel Tingkat Pendapatan

\begin{tabular}{llcc}
\hline No & \multicolumn{1}{c}{ Pernyataan/ Pertanyaaan } & Jawaban & Keterangan \\
\hline 1. & $\begin{array}{l}\text { Bapak/ Ibu sudah mampu memenuhi kebutuhan } \\
\text { sehari-hari }\end{array}$ & 3,91 & Setuju \\
2. & $\begin{array}{l}\text { Terpenuhinya kebutuhan sehari-hari dapat } \\
\text { mempermudah atau memperlancar pembayaran PBB }\end{array}$ & 4,12 & Setuju \\
3. $\begin{array}{l}\text { Bapak / Ibu menyisihkan sebagian dari pendapatan } \\
\text { untuk menabung }\end{array}$ & 4,03 & Setuju \\
\hline \multicolumn{1}{c}{ Total } & 12,06 & Setuju \\
\hline
\end{tabular}

Sumber : Data diolah 2017

\section{Pengetahuan Pajak}

Rekapitulasi skor tanggapan wajib pajak terhadap pengetahuan pajak adalah :

Tabel 9 Rekapitulasi Skor Tanggapan Variabel Pengetahuan Pajak

\begin{tabular}{|c|c|c|c|}
\hline No & Pertanyaan/ Pernyataan & Jawaban & Keterangan \\
\hline 1. & $\begin{array}{l}\text { PBB adalah pajak yang dikenakan atas bumi dan } \\
\text { bangunan seperti tanah, pekarangan, jalan tol, } \\
\text { bangunan rumah dan bangunan mewah lainnya }\end{array}$ & 4,31 & Sangat Setuju \\
\hline 2. & $\begin{array}{l}\text { PBB merupakan salah satu sumber dana } \\
\text { pembangunan di negara kita }\end{array}$ & 4,17 & Setuju \\
\hline 3. & $\begin{array}{l}\text { Tempat ibadah, makam, hutan lindung, dan museum } \\
\text { adalh objek pajak yang tidak dikenakan pajak }\end{array}$ & 4,21 & Sangat Setuju \\
\hline 4. & $\begin{array}{l}\text { Subjek PBB adalah orang pribadi atau badan yang } \\
\text { secara nyata mempunyai suatu hak atas bumi atau } \\
\text { kekuasaan atas bumi dan memperoleh manfaat atas } \\
\text { bangunan }\end{array}$ & 4,18 & Setuju \\
\hline 5. & $\begin{array}{l}\text { Saya menghitung, membayar dan melaporkan pajak } \\
\text { dengan benar }\end{array}$ & 4,13 & Setuju \\
\hline 6. & $\begin{array}{l}\text { Barang siapa melanggar undang-undang PBB akan } \\
\text { dikenakan sanksi berupa denda administratif ataupun } \\
\text { hukum penjara }\end{array}$ & 3,80 & Setuju \\
\hline & Total & 24,8 & \\
\hline & Nilai Rata-rata & 4,13 & Setuju \\
\hline
\end{tabular}




\section{Kontrol Petugas Kelurahan}

Rekapitulasi skor tanggapan wajib terhadap kontrol petugas kelurahan dilihat pada tabel 9 sebagai berikut:

Tabel 10 Rekapitulasi Skor Tanggapan Variabel Kontrol Petugas Kelurahan

\begin{tabular}{clcc}
\hline No & \multicolumn{1}{c}{ Pertanyaan/ Pernyataan } & Jawaban & Keterangan \\
\hline 1. & $\begin{array}{l}\text { Petugas kelurahan rutin dalam melakukan } \\
\text { sosialisasi tentang pentingnya membayar pajak }\end{array}$ & 3,85 & Setuju \\
2. & $\begin{array}{l}\text { Kontrol dari petugas kelurahan dapat menyadarkan } \\
\text { wajib pajak dalam membayar PBB }\end{array}$ & 3,92 & Setuju \\
3. & $\begin{array}{l}\text { Kontrol dari petugas kelurahan menjadi salah satu } \\
\text { alasan yang melatarbelakangi kamauan wajib pajak } \\
\text { untuk berlaku patuh }\end{array}$ & 3,99 & Setuju \\
4. $\begin{array}{l}\text { Melakukan tindakan kepada wajib pajak yang } \\
\text { mempunyai tunggakan }\end{array}$ & 3,72 & Setuju \\
\hline \multicolumn{1}{c}{ Total } & $\mathbf{1 5 . 4 8}$ & Setuju \\
\hline
\end{tabular}

\section{Kepatuhan Wajib Pajak}

Rekapitulasi skor tanggapan wajib pajak terhadap kepatuhan wajib pajak adalah :

\section{Tabel 11 Rekapitulasi Skor Tanggapan Variabel Kepatuhan Pembayaran PBB}

\begin{tabular}{clcc}
\hline No & Pernyataan / Perntanyaaan & Jawaban & Keterangan \\
\hline 1. & $\begin{array}{l}\text { Saya selalu mengisi SPOP sesuai dengan jumlah } \\
\text { kepemilikan bumi/bangunan }\end{array}$ & 3,87 & Setuju \\
2. & $\begin{array}{l}\text { Saya selalu melaporkan informasi terbaru } \\
\text { perihal kepemilikan bumi/bangunan kepada } \\
\text { pemerintah }\end{array}$ & 3,84 & Setuju \\
3. & $\begin{array}{l}\text { Saya selalu membayar pajak dengan tepat waktu } \\
\text { Saya selalu membayar pajak tanpa adanya } \\
\text { paksaan }\end{array}$ & 4,05 & Setuju \\
5. & Setuju \\
mema memiliki kesadaran terhadap pentingnya & 4,07 & Setuju \\
dengan tepat waktu & $\begin{array}{l}\text { Saya membayar pajak dengan teratur sehingga } \\
\text { saya tidak pernah memilki tunggakan }\end{array}$ & 4,08 & Setuju \\
Saya menghitung, membayar dan melaporkan \\
pajak dengan benar
\end{tabular}

Sumber : Data diolah 20 


\section{Pengujian Instrumen Uji Validitas}

Validitas memperlihatkan sejauh mana instrumen berguna untuk menilai apa yang akan diukur. Dalam penelitian ini uji validitas dilakukan dengan cara menghitung korelasi antara masing-masing pernyataan (item) yang berhubungan dengan tingkat pendapatan, pengetahuan pajak dan kontrol petugas kelurahan serta kepatuhan PBB di Kota Bogor.

Hasil perhitungan dengan signifikan diambil, kemudian dibandingkan nilai $r_{\text {hitung }}$ dengan alpha sebesar 0,05 maka diperoleh hasil yang berhubungan dengan tingkat pendapatan, terdiri dari 3 (tiga) item, bersumber dari hasil uji validitas untuk variabel tingkat pendapatan $\left(X_{l}\right)$ memiliki nilai $0,515>0,3$ dinyatakan valid karena $r_{\text {hitung }}>r_{\text {tabel. }}$. Pernyataan yang berkaitan pada pengetahuan pajak, terdiri dari 6 (enam) item, berdasarkan hasil uji validitas untuk variabel pengetahuan pajak $\left(X_{2}\right)$ memiliki nilai 0,546 $>0,3$ yang berarti valid karena $r_{\text {hitung }}>r_{\text {tabel. }}$ Pernyataan yang berkaitan dengan kontrol petugas kelurahan, terdiri dari 4 (empat) item, berdasarkan hasil uji validitas untuk variabel kontrol petugas kelurahan $\left(X_{3}\right)$ memiliki nilai $0,648>0,3$ dinyatakan valid karena $r_{\text {hitung }}>$ $\mathrm{r}_{\text {tabel. }}$ Dan pernyataan yang berhubungan dengan kepatuhan terdiri dari 7 (tujuh)item, berdasarkan hasil uji validitas untuk variabel kepatuhan memiliki nilai $0,686>0,3$ dinyatakan valid karena $r_{\text {hitung }}>r_{\text {tabel. }}$

\section{Uji Reliabilitas}

Berdasarkan hasil uji reliabilitas dari setiap pernyataan tentang tingkat pendapatan, pengetahuan pajak, kontrol petugas kelurahan dan kepatuhan wajib pajak reliabilitasnya 0,913 dimana nilai tersebut diatas 0,6 sehungga semua pernyataan dikatakan reliabel.

\section{Hasil dan Pembahasan}

Analisis regresi linier berganda ialah hubungan secara linier variabel independen yang lebih dari dua dengan variabel dependen. Analisis ini untuk memperkirakan nilai variabel dari variabel dependen jika hasil independen mengalami penurunan ataupun kenaikan dan untuk mendapati kenaikan arah hubungan positif atau negatif. Hasil analisis regresi linier berganda dalam penelitian ini dapat dilihat pada tabel berikut ini :

Tabel 12 Analis Regresi Linier Berganda

\begin{tabular}{|c|c|c|c|c|c|}
\hline \multicolumn{6}{|c|}{ Coefficients $^{\mathrm{a}}$} \\
\hline \multirow[b]{2}{*}{ Model } & \multicolumn{2}{|c|}{$\begin{array}{c}\text { Unstandardized } \\
\text { Coefficients }\end{array}$} & \multirow{2}{*}{$\begin{array}{c}\begin{array}{c}\text { Standard } \\
\text { ized } \\
\text { Coeffici } \\
\text { ents }\end{array} \\
\\
\text { Beta } \\
\end{array}$} & \multirow[b]{2}{*}{$\mathrm{t}$} & \multirow[b]{2}{*}{ Sig. } \\
\hline & $\mathrm{B}$ & $\begin{array}{l}\text { Std. } \\
\text { Error }\end{array}$ & & & \\
\hline $\begin{array}{ll}1 & \text { (Constan } \\
\text { t) }\end{array}$ & 1.360 & 1.503 & & .905 & .366 \\
\hline $\begin{array}{l}\text { TK } \\
\text { PEND }\end{array}$ & .250 & .113 & .100 & 2.223 & .027 \\
\hline $\begin{array}{l}\text { PENG } \\
\text { PAJ }\end{array}$ & .622 & .068 & .420 & 9.142 & .000 \\
\hline $\begin{array}{l}\text { KONTR } \\
\text { PET }\end{array}$ & .528 & .073 & .349 & 7.277 & .000 \\
\hline
\end{tabular}

a. Dependent Variable: KEPATUHAN

Sumber : Output pengolahan data dengan SPSS 20, 2017 $\mathrm{Y}=\alpha+\beta_{1} X_{1}+\beta_{2} X_{2}+\beta_{3} X_{3}++\varepsilon$

$$
\mathrm{Y}=1,360+0,250 X_{1}+0,622 X_{2}+0,528 X_{3}
$$$$
+\varepsilon
$$

Interpretasi dari regresi tersebut ialah sebagai berikut:

a. Hasil persamaan regresi tersebut diperoleh nilai konstanta sebesar 1,360 , nilai tersebut mempunyai arti bahwa jika semua variabel bebas tingkat pendapatan, pengetahuan pajak serta kontrol petugas kelurahan bernilai 0, maka kepatuhan pembayaran PBB 1,360.

b. Hasil persamaan regresi untuk variabel tingkat pendapatan sebesar 0,250. Hal tersebut menunjukan bahwa untuk setiap peningkatan tingkat pendapatan sebanyak satu satuan, dengan asumsi pengetahuan pajak dan kontrol petugas kelurahan bernilai 0 , maka menyebabkan meningkatnya kepatuhan pembayaran PBB sebesar 0,250.

c. Hasil persamaan regresi untuk variabel pengetahuan pajak sebesar 0,622. Hal tersebut menunjukan bahwa untuk setiap peningkatan pengetahuan pajak sebanyak satu satuan, dengan asumsi variabel tingkat pendapatan, pengetahuan pajak dan kontrol petugas kelurahan bernilai 0 , maka menyebabkan meningkatnya kepatuhan pembayaran PBB sebesar 0,622. 
d. Hasil persamaan regresi untuk variabel kontrol petugas kelurahan sebesar 0,528. Hal tersebut menunjukan bahwa untuk setiap kontrol petugas kelurahan sebesar satu satuan, dengan asumsi variabel, tingkat pendapatan dan kontrol petugas kelurahan bernilai 0 , maka menyebabkan meningkatnya kepatuhan pembayaran PBB sebesar 0,528.

\section{Koefisien Determinasi}

Koefisien determinasi menunjukan
seberapa besar persentase kontribusi pengarung tingkat pendapatan, pengetahuan pajak dan kontrol petugas kelurahan terhadap kepatuhan pembayaran PBB P2 di Kota Bogor. Besarnya hasil koefisien determinasi dapat dijelaskan pada tablel berikut ini:

Tabel 13 Koefisien Determinasi $\mathbf{R}^{2}$ Model Summaryb

\begin{tabular}{|c|c|c|c|c|}
\hline $\begin{array}{l}\text { Mode } \\
1\end{array}$ & $\mathrm{R}$ & $\begin{array}{c}\mathrm{R} \\
\text { Square }\end{array}$ & $\begin{array}{l}\text { Adjusted } \\
\text { R Square }\end{array}$ & $\begin{array}{c}\text { Std. Error } \\
\text { of the } \\
\text { Estimate }\end{array}$ \\
\hline 1 & $\begin{array}{r}.73 \\
6^{\mathrm{a}} \\
\end{array}$ & .542 & .538 & 3.044 \\
\hline $\begin{array}{l}\text { PENI } \\
\text { b. De }\end{array}$ & $\begin{array}{l}\text { ENC } \\
\text { dent }\end{array}$ & $\begin{array}{l}\text { G PAJ } \\
\text { Variabl }\end{array}$ & $\begin{array}{l}\text {, KONTI } \\
\text { KEPATL }\end{array}$ & $\begin{array}{l}\mathrm{ET}, \mathrm{TK} \\
\mathrm{N}\end{array}$ \\
\hline
\end{tabular}

Sumber : Output pengolahan data dengan SPSS 20,2017

Berdasarkan tabel tersebut diatas, diperoleh angka $\mathrm{R}^{2}$ ( $R$ square) sebesar 0,542 atau $(54,2 \%)$. Tabel tersebut menjelaskan bahwa kontribusi tingkat pendapatan, pengetahuan pajak dan kontrol petugas kelurahan terhadap kepatuhan pembayaran PBB sebesar 54,2\%, sedangkan sisanya $45,8 \%$ dipengaruhi atau dijelaskan oleh variabel lain yang tidak dimasukan dalam model penelitian ini.

\section{Pengujian Hipotesis}

untuk menguji apakah variabel tingkat pendapatan, pengetahuan pajak dan kontrol petugas kelurahan terhadap kepatuhan pembayaran PBB P2 di Kota Bogor berpengaruh secara simultan, maka digunakan statistik uji $f$ dengan hipotesis sebagai berikut:

$H_{0}: \beta 1, \quad \beta 2=0$; Tingkat pendapatan, pengetahuan pajak dan kontrol petugas kelurahan tidak berpengaruh secara simultan terhadap kepatuhan pembayaran PBB.
$H_{a}: \beta 1, \beta 2 \neq 0$; Tingkat pendapatan, pengetahuan pajak dan kontrol petugas kelurahan berpengaruh secara simultan terhadap kepatuhan pembayaran PBB

Untuk menguji hipotesis statistik diatas digunakan statistik uji F yang diperoleh melalui tabel Analisis Varians (Anova) seperti pada tabel dibawah ini:

\begin{tabular}{ccrrrrr}
\multicolumn{7}{c}{ Tabel 14 Uji F } \\
ANOVA
\end{tabular}

a. Dependent Variable: KEPATUHAN

b. Predictors: (Constant), KONTR PET, TK PEND, PENG PAJ

Sumber : Output pengolahan data dengan SPSS 200,2017 Berdasarkan tabel tersebut dapat diketahui bahwa hasil pengujian menggunakan uji F, diperoleh nilai Fhitung sebesar 128,552, sedangkan nilai Ftabel sebesar 2,394. Apabila Fhitung dibandingkan dengan Ftabel, maka Fhitung > Ftabel $(128,552>2,394)$ dengan nilai signifikan $F$ sebesar $0,000<0,05$. Hal ini menunjukan bahwa Ho ditolak dan Ha diterima. Kondisi ini bermakna bahwa perpajakan, tingkat pendapatan,pengetahuan pajak dan kontrol petugas kelurahan secara simultan berpengaruh signifikan dan positif terhadap kepatuhan pembayaran PBB di Kota Bogor.

\section{Uji t}

Dari perhitungan yang diperoleh hasil pengujian untuk pengaruh tingkat pendapatan, pengetahuan pajak dan kontrol petugas kelurahan terhadap kepatuhan pembayaran PBB P2 di Kota Bogor dapat dilihat pada table berikut ini:

\begin{tabular}{lccccc}
\multicolumn{5}{c}{ Tabel 15 Uji t } \\
Coefficients
\end{tabular}




\section{Tingkat Pendapatan}

Untuk melihat apakah terjadi pengaruh tingkat pendapatan terhadap kepatuhan pembayaran PBB P2 di Kota Bogor, secara statistik akan analisis menggunakan hipotesis sebagai berikut:

$H_{0}: \beta_{1}=0$ Tingkat pendapatan, secara parsial tidak berpengaruh signifikan dan positif terhadap Kepatuhan pembayara PBB.

$H_{a}: \beta_{1} \neq 0$ Tingkat pendapatan, secara parsial berpengaruh signifikan dan positif terhadap kepatuhan pembayaran PBB.

Hasil pengujian dengan menggunakan uji t diperoleh nilai thitungl untuk tingkat pendapatan sebesar 2,223, sedangkan nilai $t_{\text {tabel }}$ sebesar 1,965. Apabila $t_{\text {hitung }}$ dibandingkan dengan $t_{\text {tabel }}$ maka $t_{\text {hiyung }}>t_{\text {tabHel }}$ $(2,223>1,965)$ dengan tingkat signifikan sebesar $0,027<0,005$. Hal ini mengandung arti bahwa Ho ditolak dan $\mathrm{Ha}$ diterima. Kondisi ini bermakna bahwa tingkat pendapatan secara parsial berpengaruh terhadap kepatuhan PBB di Kota Bogor.

\section{Pengetahuan Pajak}

Untuk melihat apakah terjadi pengaruh pengetahuan pajak terhadap kepatuhan pembayaran PBB P2 di Kota Bogor, secara statistik akan dianalisis menggunakan hipotesis sebagai berikut:

$H_{o}: \beta_{3}=0$ Pengetahuan Pajak, secara parsial tidak berpengaruh signifikan dan positif terhadap Kepatuhan pembayaran PBB.

$H_{a}: \beta_{3} \neq 0$ Pengetahuan Pajak, secara parsial berpengaruh signifikan dan positif terhadap kepatuhan pembayaran PBB.

Hasil pengujian dengan menggunakan uji t diperoleh nilai thitung untuk pengetahuan pajak sebesar 9,142, sedangkan nilai $t_{\text {tabel }}$ sebesar 1,965. Apabila thitung dibandingkan dengan $t_{\text {tabel }}$ maka $t_{\text {hitung }}>t_{\text {tabel }}(9,142>1,965)$ dengan tingkat signifikan $0,000<0,005$. Hal ini menunjukan bawa Ho ditolak dan $\mathrm{Ha}$ diterima. Kondisi ini bermakna bahwa pengetahuan pajak secara parsial berpengaruh terhadap kepatuhan PBB di Kota Bogor.

\section{Kontrol Petugas Kelurahan}

Untuk melihat pengaruh kontro petugas kelurahan terhadap kepatuhann pembayaran PBB P2 di Kota Bogor, secara statistik uji hipotesis berikut ini:

$H_{0}: \beta_{4}=0$ Kontrol Petugas Kelurahan secara parsial tidak berpengaruh signifikan dan positif terhadap kepatuhan pembayaran PBB

$H_{a}: \beta_{4} \neq 0 \quad$ Kontrol Petugas Kelurahan secara parsial berpengaruh signifikan dan positf terhadaap kepatuhan pembayarn PBB

Hasil pengujian menggunakan uji $\mathrm{t}$ diperoleh nilai thitung untuk konrol petugas kelurahan sebesar 7,277, sedangkan hasil $t_{\text {tabel }}$ sebesar 1,965. Apabila $t_{\text {hitungdibandingkan }}$ dengan $t_{\text {tabel }}$ maka $t_{\text {hitung }}>t_{\text {tabel }}(7,277>$ 1,965) dengan tingkat signifikan signifikan $0,000<0,005$. Hal ini menjelaskan Ho ditolak dan $\mathrm{Ha}$ diterima. Kondisi ini bermakna bahwa kontrol petugass kelurahan secara parsiall berpengarh trhadap kepatuhan PBB di Kota Bogor.

\section{Kesimpulan}

1. Karakteristik responden untu penelitian ini lebih banyak ialah laki-laki 237 orang dengan derajat pendidikan SMA, pekerjaan karyawan swasta dan penghasilan kisaran 2.000 .000 2.999.900.

2. Tingkat pendapatan, Pengetahuan pajak serta kontrol petugas kelurahan secara simultan berpenggaruh terhadap kepatuhan PBB di Kota Bogorr

3. Tingkat pendapatan, pengetahuaan pajak dan kontrol petugs kelurahan secara parsial berpengaruh terhadap kepatuhaan PBB di Kota Bogor.

4. Besarnya kontribusi pengaruh tingkat pendapatan, pengetahuan pajak \& kontrol petugas kelurahan yaitu sebesar $54,2 \%$. Sisanya dipengaruhi variabel lainya yang tidak diteliti pda penelitian ini 


\section{DAFTAR PUSTAKA}

Devano, Sony dan Siti Kurnia Rahayu. 2006, Perpajakan:Konsep, teori dan Isu, : Kencana, Jakarta.

Kertika, D., Setiawan, A.B., Kusuma, I, 2016, Analisis Rasio Kemandirian, Rasio Efektivitas PAD, dan Rasio Efisiensi PAD pada Laporan Realisasi Anggaran Pendapatan dan Belanja Daerah (APBD) Kabupaten Sukabumi, Jurnal Akunida, Vol. 7 (2), Hal. 143-151

Mardiasmo., 2011, Perpajakan, Edisi revisi, Yogyakarta

Oktaliana,Fanie,2009,

Pengaruh

Kepemimpinan Lurah Terhadap Kesadaran Masyarakat Dalam membayar Pajak Bumi dan Bangunan, Skripsi, Universitas Sumatera Utara.

Peraturan Walikota Bogor Nomor 24 Tahun 2012 Tentang Tata Cara Pembayaran, Penyetoran, Angsuran dan Penundaan Pembayaran, serta Tempat Pembayaran Pajak Bumi dan Bangunan Perdesaan dan Perkotaan

Rahayu,Siti Kurnia.2010. Perpajakan Indonesia. Yogyakarta : Graha Ilmu

Rahayu, Siti Kurnia.2013. Perpajakan Indonesia: Konsep dan Aspek Formal. Graha Ilmu, Yogyakarta

Resmi,Siti .2005. Pepajakan Teori dan Kasus. Salemba Empat, Jakarta

Rosdiana,Haula. 2003. Ketentuan Umum dan Tata Cara Perpajakan. Pusat kajian Departemen Ilmu Administrasi FISIP UI, Depok:

Saptono, Bambang Suteng.2006. Sosiologi untuk SMA Kelas $X$. Jakarta : Phibeta

Simanjuntak, Elizabeth. 2008. Analisis Faktor-faktor yang Mempengaruhi Kesadaran Masyarakat dalam Membayar Pajak. Skripsi. Yogyakarta : FE UGM.
Soedibjo, Bambang S.,2004. Pengantar Metode Penelitian, Edisi Revisi, jurusan Sekolah Tinggi Ilmu ekonomi, Bandung

Soemitro, Rochmat. 1987. Asas dan Dasar Perpajakan. Bandung : Eresco

Sugiyono. 2013. Metode Penelitian Manajemen. Alfabeta, Bandung

Supardi.2014. Aplikasi Statistik dalam Penelitian. Jakarta : Change Publication 